\title{
Motor skills in pre-school education and affects to 5 year old children's psychomotor development
}

\section{Ugur SENTURK1, Malik BEYLEROGLU², Faruk GUVEN³, Atike YILMAZ4, Hakan AKDENIZ 5}

${ }^{1}$ Çanakkale Onsekiz Mart University, School of Physical Education and Sports, Çanakkale, Turkey.

2 Sakarya University, School of Physical Education and Sports, Sakarya, Turkey.

${ }^{3}$ Kilis 7 Aralik University, School of PhysicalEducation and Sports, Kilis, Turkey.

${ }^{4}$ Sakarya University, School of PhysicalEducation and Sports, Sakarya, Turkey.

${ }^{5}$ Kocaeli University, School of PhysicalEducation and Sports, Kocaeli, Turkey.

Address Correspondence to U. Senturk,ugursenturk@comu.edu.tr.

\begin{abstract}
This study aimed to investigate the effect of the motor acquisitions placed in pre-school education program on the psychomotor development of 5 year-olds group children. In 2014-2015 school year, pre-school 5 year-old sex perimental group $(n=55)$, control group $(n=45)$ totally 100 children participated in. In order to measure the motor performances of control and experiment groups, the motor performance test protocol that, as pre-test, Morris, Atwater Williams and Will more performed in 1980 wasused. While the program of "Educational Play Activity Towards The Acquisitions About The Motor Development Placed in The Ministry of National Education Pre-School Program" wasapplied for the experimental group as 40 minutes for 2 days in a week for 8 weeks, Physical Activity wasappliedfor Control group as 10 minutes foreverymorning and 5 days in a week. The difference between pre-test and post-test was analysed by Paired-Samples t-test. The Differences between experimental group and control group were analysed by independent-Samples t-Test. The pre-test values of the experimental and control groups in the investigation were analysed by Independent Samples t-Test. The difference between control and experimental groups accordingto the analysis results of Promptness, Long Jump by Standingand Throwing Tennis Ball tests wasn't found important statistically $(\mathrm{p}>0,05)$. Accordingto the analysis results of Balance, Speedand Catchingtests, significant difference was found statistically between the control andexperi mental group ( $\mathrm{p}<0.05)$. The difference among the test averages of Long Jump by Standing and Throwing Tenis Ball of the control group wasn't foundsignificant ( $\mathrm{p}>0.05)$. The difference between pre-test and post-test belongingto experimental group was analysed by paired t-test. The difference among Promptness, Long Jump by Standing, Stand In Balance On OneFoot, Throwing Tennis Ball, Sprint and Catchingtests was foundsignificant statistically $(\mathrm{p}<0.05)$. It is understood that regularimplementation of Motor Acquisitions Placed in Pre-School Education Curriculum on 5 Year-Olds Group Children can develop the motor performances such as Balance, Speed and Catching skills significantly.
\end{abstract}

Keywords: Motor acquisition, pre-school, psychomotor development.

\section{INTRODUCTION}

In a manner that requires action in order to sustain human life more healthy and qualified. This is a lifelong activity. Motor development, physical growth and development of the central nervous system primarily in parallel with the gain can be interpreted as the mobility of the organism. Motor development include in physiological and biological changes in the direction of movement skills, as well as in interaction with other developmental areas (10). The action which starts with the reflexes of a child's development follows and high-level skills leads to a process. Simple movements at first, when it occurs as a result of reflexive movements, the child of this movement complex movement skills that allows it to be a social person later. Motor development; reflexive movement, primitive actions, and specialized basic movements including movements are considered as four semesters (5). If you are rich and appropriate training opportunities offered to children between the ages of 2-7 stimulants, it develops basic motor skills. During adolescence and adulthood, this is foundation for success in sports skills (8).

The main tool of communication is the movement of a child's preschool. In other words, through movement can articulate their feelings and desires. In early childhood education children's 
long-term movements in strength or have the power to resume their position, or with an attempt of balance, rhythm and movement can improve their ability in fluency. Pre-school education of children of 36-72 months in cognitive, social-emotional, language and cognitive development, the promotion of self-care and elementary school, it is intended to equip students with skills to be ready for the discovery. In preschool education, for these purposes, a daily programme which is in parallel with the motor development of children in physical activities is included as well as social, sensory, and contributes to their cognitive development. Play and movement education activities for the children of age-specific development is an important tool for ensuring easily fulfill their homework (18). In the process of rapid growth and development, which were the pre-school age children in the game. The game plays a major role in giving direction to the child's life. The best activity of the movement performance, the game. Is required to play a child's game because there is a need for the Game Boy. For the child, which is a very serious hobby game, also funny, is the source of learning and development. The game supports the child's psychomotor, intellectual, language, social and emotional development. At the same time to adapt the child's moral rules and values plays a big role in the game. When you grow up, if children don't play the game when they are young, their behavior may be affected by the situation because it is known that the child begins to learn the game for their future role. A child in preschool acts like, by observing those around him, they have mimics with their movements. Children also receive from the world outside the imagination of Qatar, and interpret it their own way by integrating the games reflects. If the child is observed while playing the game, that can be obtained his thoughts and feelings belongs to the lot of information. Children who can't control their emotions, problems and uncomfortable through the game that can hit, without realizing it, adults can lead to the inner world. At the same time the child, feel free of impulses through the game. Today, thanks to technological developments and living conditions, adults don't have time to play. Can't find the time to devote to the game to play the children's game of adults who play the game too, because they must be interfering blocked the healthy development of a child are expected. Adults also participate in the children's games, should create the appropriate environment for them to play in the game. This takes place if the children play with confidence and feel comfortable in the environment the game where he will play. The child should not be restricted to play the game; however, the child should be treated as needed. It shouldn't just be training the goal of the game at the same time, the child should be to take pleasure from the game and have fun.

In this study, it is aimed to pre-school, a period where ability to move can be made the most positive and lasting contributions. This term covers the various stages of development that can give direction to all life. Age appropriate training in child sensitive programmes to accelerate is known the development of the circuits. Thus, in this study was conducted the early childhood education program in the educational attainment of children in the age group of age 5 of the motor for the investigation of the effect of psychomotor development".

\section{MATERIAL \& METHOD}

This research surveys in Çanakkale Onsekiz Mart University of Continuing Education in the academic year 2014-2015 preschool children's house 60 children in the age group 5 (experimental group) Group who are continuing in the preschool education, Çanakkale Kepez 55 children that 5 years of age (control group) for a total of 115 children were participated. Research model of this study in quantitative research methods, the experimental method, pre-and post-test control group design will be used. Experimental group 2 days per week for 8 weeks, 40 minutes "the Ministry of national education motor development in the preschool education program for the attainment of educational game Event" the program is being applied, while the control group was applied to 10 minutes of physical activity 5 days a weekverymorning.

Data collection: During the first week of the study to measure the performance of motor control and experimental groups pre-test to Morris et al. (14), and was used the engine performance when performed in 1980 Willmore test protocol. In 1986 in Turkey, 3-6 years old, 205 children on this test is applied, balance on one foot quickness, stop, capture, standing long jump, throwing, and consists of 6 tests including running (15). In order to measure motor performance of preschool children in the stopping on one foot balance test, standing long jump, short distance running speed, the ball consists of trapping tests and anthropometricmeasurements.

Data analysis: The data obtained in this study by taking the average and standard deviation between the groups pre-test post-test differences by student's 
$\mathrm{t}$ test for independent samples will be analyzed and will be compared to the difference between anthropometric measurements. All data obtained in the analysis of the data descriptive statistics will be calculated using SPSS-15 using the program package.

\section{RESULTS}

The results of the analysis of the data obtained from the research are given in the tables below.

Respondents that belong age, height and body weight averages and test-statistical results of the comparison between control groups are presented in Table 1 . The averages of age and body weight were similar to the experimental and control groups ( $p>0.05)$ higher than the control group to the experimental group has been found to have an average of stature $(\mathrm{t}=-2.784 ; \mathrm{p}<0.05)$.
As shown in Table 2, the quickness of the control group, don't balance on one foot, sprint and capture the initial and final values of the test were conducted to determine whether there is a significant difference between the averages of the associated t-test the difference between group means was statistically significant $(\mathrm{p}<0.05)$. Throw a tennis ball, long jump and the Standing of the control group, the difference between the averages of the tests were not significant $(p>0.05)$.

As can be seen in Table 3, the experimental group pre - test and post-test results were analyzed with comparing. According to the results of the analysis in Table 2, quickness, standing long jump, balance on one foot, throw a tennis ball, and capture the difference between sprint tests found to be statistically significant $(\mathrm{p}<0.05)$.

Table 1. The experimental and control groups in age, height, body weight, mean and standard deviation values of the results.

\begin{tabular}{llccccc}
\hline Variables & Group & $\mathrm{N}$ & Mean & Std. Deviation & $\mathrm{t}$ & $\mathrm{p}$ \\
\hline \multirow{3}{*}{ Age (year) } & Control & 45 & 4.50 & 0.51 & & \\
& Experiment & 55 & 4.50 & 0.51 & 0.000 & 1.000 \\
\multirow{2}{*}{ Height $(\mathrm{cm})$} & Control & 45 & 109.70 & 6.21 & & \\
& Experiment & 55 & 112.96 & 5.47 & -2.784 & $0.006^{*}$ \\
Weight (kg) & Control & 45 & 20.19 & 4.03 & & \\
& Experiment & 55 & 20.92 & 3.35 & -0.988 & 0.326 \\
& & & & & & \\
\hline
\end{tabular}

Table 2. Control group pre - and post-test comparison of results.

\begin{tabular}{lcccc}
\hline Variables & Differences Mean & S. Deviation & $\mathrm{t}$ & $\mathrm{P}$ \\
\hline & & & & \\
Balance (sn) & -.31 & .34 & -5.348 & $.000^{*}$ \\
Quickness (sn) & -.16 & .21 & -4.363 & $.000^{*}$ \\
Speed (cm) & -.15 & .13 & -6.613 & $.000^{*}$ \\
Capture (sn) & -.10 & .25 & -2.394 & $.022^{*}$ \\
D long jump (cm) & -.13 & 1.85 & -.410 & .684 \\
T. T. Throw a ball (m) & -1.26 & 7.97 & -.933 & .357
\end{tabular}

${ }^{*} \mathrm{p}<0.05$

Table 3. The experimental group pre - test and post-test comparison of results.

\begin{tabular}{lcccc}
\hline Variables & Differences Mean & S. Deviation & $\mathrm{t}$ & $\mathrm{P}$ \\
\hline & & & & \\
Balance (sn) & -4.37 & 2.69 & -9.989 & $.000^{*}$ \\
Quickness (sn) & -.66 & .88 & -4.639 & $.000^{*}$ \\
Speed (cm) & -.52 & .45 & -7.116 & $.000^{*}$ \\
Capture (sn) & -.51 & .44 & -7.122 & $.000^{*}$ \\
D Long jump (cm) & -14.11 & 10.10 & -8.608 & $.000^{*}$ \\
T. T. Throw a ball (m) & -1.00 & 1.51 & -4.075 & $.000^{*}$ \\
& & & &
\end{tabular}


Table 4. The experimental and control groups pre-test comparison of results.

\begin{tabular}{llllcll}
\hline Variables & Group & $\mathrm{N}$ & Mean & S. Deviation & $\mathrm{t}$ & $\mathrm{P}$ \\
\hline \multirow{3}{*}{ Balance (sn) } & Kontrol & 30 & 30.44 & 16.31 & 6.284 & $.000^{*}$ \\
& Deney & 30 & 11.85 & 7.83 & 6.122 & .000 \\
Quickness (sn) & Kontrol & 30 & 7.10 & 1.16 & -1.283 & .204 \\
& Deney & 30 & 7.49 & 1.40 & -1.293 & .200 \\
Speed (cm) & Kontrol & 30 & 4.12 & .442 & 4.560 & $.000^{*}$ \\
& Deney & 30 & 3.69 & .37 & 4.526 & .000 \\
Capture (sn) & Kontrol & 30 & 2.01 & .57 & 2.218 & $.030^{*}$ \\
& Deney & 30 & 1.70 & .63 & 2.227 & .029 \\
D Long Jump (cm) & Kontrol & 30 & 75.27 & 13.34 & 1.345 & .183 \\
& Deney & 30 & 70.21 & 18.21 & 1.362 & .178 \\
T. Throw a ball (m) & Kontrol & 30 & 4.76 & 1.57 & 1.535 & .129 \\
& Deney & 30 & 4.18 & 1.67 & 1.539 & .128 \\
& & & & & & \\
\hline
\end{tabular}

Table 5. Comparison of the results of the last test of the experimental and control groups.

\begin{tabular}{lllllll}
\hline Variables & Groups & $\mathrm{N}$ & Mean & S. Deviation & $\mathrm{t}$ & $\mathrm{P}$ \\
\hline \multirow{2}{*}{ Balance (sn) } & Experiment & 30 & 7.74 & 1.74 & -9.989 & $.000^{*}$ \\
& Control & 30 & 9.46 & 2.26 & 5.348 & .000 \\
Quickness (sn) & Experiment & 30 & 5.22 & 1.22 & 4.639 & $.000^{*}$ \\
& Control & 30 & 6.47 & 1.02 & 4.363 & .000 \\
Speed (cm) & Experiment & 30 & 12.44 & 3.09 & 7.116 & $.000^{*}$ \\
& Control & 30 & 9.60 & 2.33 & 6.613 & .000 \\
Capture (sn) & Experiment & 30 & 4.65 & .71 & 7.122 & $.000^{*}$ \\
& Control & 30 & 5.17 & .75 & 2.394 & .022 \\
D Long Jump (cm) & Experiment & 30 & 2.58 & .50 & 8.608 & .000 \\
& Control & 30 & 2.02 & .55 & -.410 & .684 \\
T. Throw ball (m) & Experiment & 30 & 59.40 & 15.33 & 4.075 & .000 \\
& Control & 30 & 56.48 & 16.42 & -.933 & .357
\end{tabular}

As it can be seen in Table 4, the experimental and control groups' pre-test values were analyzed with the $t$ test for independent samples. Quickness, Standing long jump and throw a tennis ball according to the results of the analysis of tests, the difference between experimental and control groups was not statistically significant $(p>0.05)$. Balance, speed and capture according to the results of the analysis of tests, no statistically significant difference between the experimental and control groups was found $(\mathrm{p}<0.05)$.

As can be seen in Table 5, the experimental and control groups were analyzed with independent samples t-test values for the final test. The results of the analysis of standing long jump and tennis ball throw tests, according to the difference between experimental and control groups was not statistically significant ( $p>0.05)$. Balance, Quickness, speed, and according to the results of the analysis of capture tests, no statistically significant difference between the experimental and control groups was found $(\mathrm{p}<0.05)$.

\section{DISCUSSION}

In their study of the application of the displacement of the participating children skill 
points organized in many different ways, differ significantly from the scores of free play activities for the children involved, so of applications that can be organized in many different ways has positive effects on the displacement of the skills of the children stated (19). In game skills in preschool children in the age group of 5-6 workouts has examined the impact of the displacement. As a result, game-skill scores of the children participating in the exercise program in the experimental group found no statistically significant difference in displacement $(p<.01)$. Object control subtest scores between the experimental and control group of children in that there was a significant difference in favor of the experimental group are presented in Table 3. Object control skills of the planned activities expressed movement education developed $(7,17)$. pre-school children's motor competence and perceived object control skills pre-test and post test scores showed a significant difference between the groups stated. Central motor skills object control skills applied to the group who would be treated with no significant difference among the group was seen $[F(1,69)=45.81, p=.00]$. It has done a lot of research for the development of large motor skills activities planned for the decisive actions of children. (1,3,4,12,13). His study of preschool education institutions ongoing education of children 5-6 children in the age group influenced the development of physical and motor movement that is applied to another study that suggested that in (7). Administered a program to disadvantaged children motor skill, motor skill development of disadvantaged children and planned a program with the stated findings that contribute to motor $[F(1,57)=134.23, p<.05]$. In a different survey, creative movement and motor skills of children in the age range of 3-5 program applied to large, it was observed that differed before and after training (20). The results of the study, the children in the experimental group implemented a training program basic movement running, gallop, one foot, jumping, running, jump over obstacles, and spatial skills long jump with bouncing ball, hold the ball, the ball with the foot hitting the ball, throwing the ball and rounding skills large motor skills are more successful in experiment shows.

The Ministry of Education can be made to work in preschool education program, child development, preschool education and experts in the fields of physical education, in collaboration for the development of fundamental movement skills in relation to the realignment of the goals and achievements in the area of motor development.

Pre-school educational institutions, the education of the children act it is important to have physical conditions that make the provision of the necessary infrastructure for this support which stipulates that the regulations can be provided and for the creation of new institutions by the Ministry of education.

In bachelor programs, a term which in addition to motor skills and motor learning for Physical Education and games course introduction and application of theoretical knowledge courses more than giving weight to the field equipped to contribute to the growth of teachers.

Movement education can be made with family participation practices in motor development of the children by giving about how place affects studies. Also, movement education can be made for motor development of children that it affects about how giving more room to the applications in the studies.

\section{REFERENCES}

1. Altınkök M. Temel Motor Hareketlerin Gelistirilmesini İçeren Özel Beden Egitimi Program Tasarısının 5-6 Yas Çocukların Temel Motor Hareketlerin Gelisimine Etkisinin Arastırılması. Master Thesis, Marmara University, Institute of Education Sciences, İstanbul, 2006.

2. Ayan V, Mülazimoğlu O. Talent Selection in Sports and Assessment of the Physical Characteristics and Some Performance Profiles of Male Children Between 8-10 Years Old in Guidance to Sports (Ankara Sample). Firat University Journal of Health Sciences, 2009; 23(3): 113-118.

3. Çelebi B. Hareket eğitiminin okulöncesi eğitim kurumlarındaki 5-6 yaş grubu çocuklarda fiziksel ve motor gelişime etkisi. Master Thesis, Mugla University, Institute of Social Sciences, Muğla, 2010.

4. Dursun Z. Temel becerileri içeren özel beden eğitimi program tasarısının okulöncesi 6 yaş çocukların motor beceri erişileri üzerine etkisi. Master Thesis, Hacettepe University, Ankara, 2004.

5. Gallahue DL, Ozmun JC. Understanding Motor Development: Infants, Children, Adolescents, Adults (6th ed.). Boston, MA: McGraw-Hill. 2006.

6. Gallahue D. Understanding Motor Development in Children, John Wiley and Son, New York. 1982.

7. Goodway JD, Branta CF. Influence of a motor skill intervention on fundamental motor skill development of disadvantaged preschool children. Research Quarterly for Exercise and Sport, 2003; 74(1): 36-47.

8. Graham G. Teaching Children Physical Education Becoming Master A Teacher. Human Kinetics Books, s.23-24, USA, 1992.

9. Haywood K. Life Span Motor Development. Human Kinetics Book, Champaign, Illinois, USA, 1998. 
10. Haywood KM, Getchell N. Lifespan Motor Development (5th ed.). Champaign, IL: Human Kinetics. 2009.

11. Hoffman J. The influence of motor skill interventions on disadvantaged children. Journal of Physical Education Recreation ve Dance, 2003; 74(8): 14-16.

12. Kerkez F. Effect of the enhanced play-movement program on kindergarden children's locomotor skills. Hacettepe University J Spor Sciences, 2004; 15(2): 76-90.

13. Kırıcı HM. Okulöncesi eğitim kurumlarındaki 4-6 yaş grubu çocuklarda 8 haftalık hareket eğitiminin motor performanslarına etkisi. Master Thesis, Muğla University, Institute of Social Sciences, Muğla, 2008.

14. Morris MA, Atwater EA, Williams JM, Wilmore HJ. Motor Performance and Antropometric Screening Measurements for Preschool Age Children. A.M. Morris (ed.), Motor Development: Theory into Practice, Managroph 3 Motor Skills. 1980.

15. Özer DS, Özer K. Çocuklarda Motor Gelişim. Ankara: Nobel Yayıncilık, 2004.
16. Robinson LE, Goodway JD. Instructional climates in preschool children who are at risk. Part I: object control skill development. Research Quarterly for Exercise and Sport, 2009; 80(3): 533-542.

17. Robinson LE, Rudisill ME, Goodway JD. Instructional climates in preschool children who are at risk. Part II: perceived physical competence. Research Quarterly for Exercise and Sport, 2009; 80(3): 543-551.

18. Topkaya İ, Serbes Ş. Okulöncesi Eğitiminde "Oyun ve Hareket Etkinlikleri" Okul Öncesinde Psikomotor Alan Eğitimi. 1. Bask1, pp. 170, 2012.

19. Zachopoulou E, Bakle I, Deli E. Implementing intervention movement programs for kindergarten children. J Early Child Res, 2006; 4(1): 5-18.

20. Wang JH. A Study On Gross Motor Skills Of Preschool Children. Journal of Research in Childhood Education, 2004; 19(1): 32-43. 